\title{
PENGARUH LATIHAN AEROBIK TERHADAP PENURUNAN KETEBALAN LEMAK SUBKUTAN
}

\author{
Wahyana Mujari Wahid ${ }^{1}$, Arimbi MB ${ }^{2}$ \\ Program Studi Ilmu Keolahragaan, Fakultas Ilmu Keolahragaan, Universitas Negeri Makassar ${ }^{1,2}$ \\ Email: wahyana.mujari@unm.ac.id
}

\begin{abstract}
ABSTRAK
Penelitian ini bertujuan untuk mengetahui pengaruh latihan aerobik terhadap penurunan indeks massa tubuh dan penurunan ketebalan lemak subkutan. Penelitian ini adalah penelitian Experiment yang hanya menggunakan satu kelompok perlakuan tanpa menggunakan kelompok kontrol. Penelitian dilakukan selama 12 minggu dengan frekuensi latihan 3 kali seminggu dengan durasi latihan 30 menit. Adapun latihan aerobik yang diberikan adalah jogging. dengan standar training zone 60\% - 80\% kali denyut nadi maksimal (DNM). Desain penelitian menggunakan one group pretest-postest dan menunjukkan hasil yang signifikan dengan aktifitas latihan aerobik. Pengambilan data dilakukan sebelum dan sesudah latihan. Populasi dalam penelitian ini adalah remaja putra atau siswa SMAN 3 Takalar, sedangkan sampel dalam penelitian ini berjumlah 25 orang yang ditentukan dengan menggunakan teknik purposive sampling. Berdasarkan hasil penelitian dan pembahasan, dapat ditarik kesimpulan bahwa terdapat pengaruh yang signifikan latihan aerobik terhadap penurunan indeks massa tubuh dan ketebalan lemak subkutan. Indeks massa tubuh diperoleh $t_{\text {hitung }}$ sebesar 13,981 dan nilal $p=0.000(p<0,05)$. Sementara lemak tubuh diperoleh $t_{\text {hitung }}$ sebesar 13,063 dan nilai $p=0,000(p<0,05)$. Ini membuktikan bahwa ada pengaruh yang signifikan latihan aerobik terhadap penurunan indeks massa tubuh dan penurunan ketebalan lemak subkutan.
\end{abstract}

Kata kunci: Lemak Tubuh; Lemak Subkutan; Aerobik; IMT

\begin{abstract}
This aims of this study is to determine the effect of aerobic exercise on decreasing the index of the body mass and decreasing the subcutaneous thickness of body fat. This study is an experimental study that only used one treatment of group without using a control group. The study was conducted for 12 weeks with a frequency of exercise 3 times a week with an exercise duration of 30 minutes. The aerobic exercise given is jogging with the standard training zone 60\%-80\% times the maximum pulse rate. The research design used one group pretestposttest and showed significant results with aerobic exercise activities. Data collection was carried out before and after the exercise. The population in this study were young men or students of SMAN 3 Takalar, while the sample in this study amounted to 25 people who were determined using purposive sampling technique. Based on the results of research and discussion, conclusions can be drawn that there was effect of aerobic exercise on decreasing the index of the body mass and decreasing the subcutaneous thickness of body fat. The index of body mass obtained around of 13,981 and p value $=0.000(p<0.05)$. Meanwhile, the body fat obtained was calculated at 13.063 and the value of $p=0.000(p<0.05)$. This proves that there is a significant effect of aerobic exercise on decreasing the index of body mass and the subcutaneous thickness of body fat.
\end{abstract}

Key Words : The body fat, the subcutaneous fat, aerobics, IMT

Dipublikasikan Oleh :

UPT Publikasi dan Pengelolaan Jurnal

Universitas Islam Kalimantan Muhammad Arsyad Al-Banjari Banjarmasin 


\section{PENDAHULUAN}

Kegemukan adalah suatu keadaan dimana terjadi kelebihan berat badan $10 \%$ ditas berat badan ideal atau jumlah persentase lemak tubuh melebihi $20 \%$ untuk laki-laki dan $25 \%$ untuk perempuan. Kegemukan dan obesitas merupakan salah satu faktor yang menjadi penyebab dari penyakit tidak menular yang bersifat kronis. Kegemukan merupakan penyakit yang kompleks karena melibatkan interaksi dari beberapa faktor resiko, antara lain kelebihan makanan, kurang gerak atau olahraga, faktor psikogen, gangguan endokrin, gangguan metabolisme lemak, dan genetik. Kegemukan dan obesitas disebabkan oleh ketidakseimbangan kalori yang di konsumsi di banding pengeluaran. Pada umunya kondisi overweight dan obesitas merupakan kondisi dimana terdapat lemak yang berlebih di dalam tubuh, sehingga dapat menimbulkan resiko terhadap tingkat kesehatan individu dan merupakan faktor penyebab dari munculnya penyakit - penyakit degeneratif. Perbedaan antara kondisi overweight atau obesitas pada individu yaitu dengan cara melakukan perhitungan Indeks Massa Tubuh (IMT). Menurut (P2PTM Kemenkes, 2018) cara menghitung IMT dengan menggunakan berat badan dalam satuan kilogram dibagi kuadrat tinggi badan dalam satuan meter, berikut klasifikasi berat badan berdasarkan IMT:

Tabel 1. Klasifikasi Berat Badan Berdasarkan IMT.

\begin{tabular}{ll}
\hline \multicolumn{1}{c}{ KATEGORI } & \multicolumn{1}{c}{ IMT } \\
\hline Berat Badan kurang & $<18,5 \mathrm{~kg} / \mathrm{m} 2$ \\
\hline Normal & $18,5-22,9 \mathrm{~kg} / \mathrm{m} 2$ \\
\hline Berat badan lebih (Overweight) & $23-24,9 \mathrm{~kg} / \mathrm{m} 2$ \\
\hline Obesitas I & $25-29,9 \mathrm{~kg} / \mathrm{m} 2$ \\
\hline Obesitas II & $>30 \mathrm{~kg} / \mathrm{m}$ \\
\hline
\end{tabular}

Menurut (Nurhayati, 2018) obesitas merupakan salah satu faktor resiko penyakit tidak menular yang bersifat kronis seperti hipertensi dan diabetes. Tetapi obesitas merupakan salah satu faktor resiko yang dapat dimodifikasi. Maka dari itu, obesitas menjadi salah satu fokus utama dari WHO dalam mengurangi angka penyakit tidak menular. Kegemukan merupakan salah satu faktor resiko penting dari berbagai penyakit dan dapat mengurangi keindahan bentuk tubuh.

Kalori diperoleh dari makanan sedangkan pengeluarannya melalui aktivitas tubuh dan olahraga. Kalori terbanyak (60-70\%) dipakai oleh tubuh untuk kehidupan dasar seperti bernapas, jantung berdenyut dan fungsi dasar sel. Besarnya kebutuhan kalori dasar ini ditentukan oleh genetik atau keturunan. Namun aktivitas fisik dan olahraga dapat meningkatkan jumlah pengeluaran kalori. Aktifitas fisik merupakan salah satu penggunaan energi oleh tubuh, disamping metabolisme basal dan SDA (Specifik Dinamic Action) dari bahan makanan. Seseorang yang tidak beraktifitas fisik atau dalam keadaan santai (sedentary), aktivitas fisiknya sekitar separuh dari energi metabolisme basal, sedangkan orang yang dengan aktifitas fisik sangat tinggi paling banyak setara dengan energi metabolisme basal (Azrimaidaliza et al., 2020) Bila kalori yang masuk berlebihan dan tidak diimbangi dengan aktifitas fisik yang seimbang akan memudahkan orang mengalami kegemukan. Meningkatnya kesibukan juga menyebabkan seseorang tidak lagi mempunyai waktu yang cukup untuk berolahraga secara teratur (Kurdanti et al., 2015). Kebiasaan hidup santai, malas bergerak, selalu dibantu oleh orang lain dan makan berlebihan akan meningkatkan asupan dan menurunkan luaran kalori. Minyak atau lemak merupakan komponen bahan makanan yang penting, istilah minyak atau lemak sebenarnya tergantung apakah pada suhu kamar bahan tersebut dalam keadaan cair atau padat. Bila pada suhu kamar dalam keadaan cair maka disebut minyak sebaliknya biladalam keadaan padat disebut lemak. Pengaturan pola makan merupakan pilar utama dalam mengontrol lemak dalam tubuh. Kadar lemak dalam tubuh dapat berubah-ubah tergantung pola makan dan aktifitas fisik seseorang. Lemak cenderung dapat meningkat pada orang yang kegemukan dan kurang aktifitas fisik. Dari suatu hasil penelitian yang membandingkan antara diet dan aktivitas, ditemukan bahwa aktivitas dapat menurunkan jumlah lemak dan kadar lemak dalam darah. Disamping itu aktivitas dapat meningkatkan kolesterol baik (HDL). Peningkatan aktivitas secara terorotis dihubungkan dengan meningkatkan sirkulasi kolateral di jantung yang dapat membantu pada saat serangan jantung (Yani, 2015).

\section{Dipublikasikan Oleh :}

\section{UPT Publikasi dan Pengelolaan Jurnal}

Universitas Islam Kalimantan Muhammad Arsyad Al-Banjari Banjarmasin 
Peningkatan timbunan lemak tubuh akan membawa resiko berbagai macam penyakit, seperti penyakit jantung, penyakit diabetes dan berbagai akibat dari hypokinetic, serta dampak psikologis yang pada umumnya dirasakan wanita ialah merasa malu dan rendah diri karena kelebihan berat badan. Banyak wanita menginginkan tubuh yang sehat, ramping dan indah dipandang mata. Bila asupan makanan mengandung banyak kalori (energi), namun energi hanya digunakan sedikit saja untuk beraktivitas, maka kelebihan energi akan ditimbun dalam bentuk lemak. (Kandinasti, 2018) menyatakan bahwa penyebab utama terjadinya kelebihan berat badan adalah asupan makan lebih yang lebih besar dibandingkan energi yang diperlukan untuk aktivitas.

Aktivitas fisik adalah penting dilakukan sebagai bagian dari gaya hidup sehat, dan perlu didukung asupan gizi yang seimbang. (Oktriani, 2019) menulis bahwa untuk mendapatkan tubuh yang sehat dan bugar perlu ditunjang dengan kegiatan olahraga atau latihan fisik secara teratur dan terukur sesuai dengan kebutuhan tubuh. Perlu diterapkan prinsip 3G yaitu: gizi cukup, gerak cukup dan gaya hidup yang baik. Seseorang yang sehat dapat melakukan aktivitas fisik setiap hari tanpa kelelahan yang berarti. Olahraga harus dilakukan secara teratur. Macam dan takaran olahraga berbeda menurut usia, jenis kelamin, jenis pekerjaan dan kondisi kesehatan.

Aktivitas fisik bermanfaat bagi setiap orang karena dapat meningkatkan kebugaran, mencegah kelebihan berat badan, meningkatkan fungsi jantung, paru dan otot serta memperlambat proses penuaan. Olahraga dengan intensitas yang tidak tinggi namun dalam waktu yang lama akan menggunakan lemak sebagai bahan untuk dimetabolisasi, dijadikan energi dalam bentuk ATP. (Listiarini et al., 2018)menemukan bahwa latihan aerobik 34 hari/minggu, 30-45 menit per sesi latihan, akan menurunkan konsentrasi serum leptin sampai 17,5\% setelah berlatih 12 minggu. (Susiwati et al., 2018) menyatakan bahwa penurunan kadar trigliserida plasma dan peningkatan kadar kolesterol HDL terjadi 18-48 jam setelah melakukan latihan fisik, hal tersebut membuktikan bahwa latihan fisik dan satu sesi latihan fisik menimbulkan pengaruh yang berbeda tetapi saling berhubungan.. Untuk membuat pilihan olah gerak yang lebih banyak dalam usaha menurunkan berat tubuh dan mengurangi lemak, perlu pengembangan olah gerak secara profesional, salah satu cara yang praktis, mudah dilakukan, biaya terjangkau adalah dengan latihan aerobik. Aktivitas aerobik merupakan aktivitas dengan intensitas rendah sedang yang dapat dilakukan secara kontinyu dalam waktu yang cukup lama (Dinata et al., 2020). Latihan aerobik secara signifikan meningkatkan kapasitas dari kontrol pernapasan dan tulang, pada saat latihan otot berkontraksi lebih luas dan lebih banyak mitokondria dari pada serabut otot yang aktif, struktur mitokondria cenderung kapasitasnya menigkat, perubahan hasil enzim dari perubahan total mitokondria dari pada peningkatan aktivitas enzim setiap protein dari unit mitoondria (Lesmana et al., 2018). Direkomendasikan agar orang yang ingin menurunkan berat badan mulai meningkatkan aktivitas fisik mereka agar lebih aktif secara umum seperti naik turun tangga, berjalan, senam aerobik adalah hal-hal yang yang lebih efektif membakar kalori dan mengurangi lemak tubuh (Sientia \& Puruhita, 2012).

Ada beberapa jenis aerobik yang disesuaikan dengan tingkat kemampuan individu. Keterampilan, kesehatan dan kenyamanan adalah hal-hal yang harus dipertimbangkan terlebih dahulu. Beberapa dari jenis tersebut diantaranya adalah: High Impact Aerobic, yaitu latihan aerobik yang dilakukan dengan tempo yang lebih cepat dan intensif. Contohnya, berlari, jogging, bersepeda, senam aerobik), dan lainnya. Low Impact Aerobik, yaitu latihan aerobik yang dilakukan dalam intensitas sedang. Latihan ini baik bagi Anda yang sedang menjalani proses penyembuhan dari cedera, wanita hamil, ataupun lansia. Contoh latihannya yaitu, jalan kaki dan latihan aerobik dalam air.

METODE

Penelitian ini merupakan studi pre eksperimen atau pre-ekperimental yang merupakan penelitian yang digunakan untuk mencari hubungan sebab-akibat dimana randomisasi tidak dilakukan dan tidak menggunakan kelompok kontrol. Desain penelitian menggunakan the one-group Pre-posttest Design. Pada penelitian ini dipilih sekelompok subjek atau unit eksperimen. Sebelum diberikan perlakuan, dilakukan pengukuran (pre test) kemudian diberikan perlakuan dan pada akhir kegiatan atau setelah diberikan perlakuan, dilakukan pengukuran kembali (post test). Hasil pengukuran pre dan post test akan dibandingkan untuk melihat perbedaan nilai variabel setelah diberikan intervensi. Teknik sampel yang digunakan adalah purposive sampling dengan kriteria siswa yang memiliki kelebihan berat badan dan berjenis kelamin laki-laki. Sampel dalam penelitian ini adalah siswa SMAN 3 Takalar yang berjumlah 25 orang. Pengkategorian berat badan dilakukan berdasarkan rumus Indeks Massa Tubuh (IMT). Sampel sebelumnya dilakukan pengukuran tinggi dan berat badan untuk memperoleh IMT, selanjutnya dilakukan pengukuran lemak subkutan pada bagian (bicep, subscapula, abdominal dan thigh) menggunakan alat skinfold caliper. Total lemak tubuh diperoleh dari menjumlah tebal lemak subkutan pada 4 daerah pengukuran kemudian mempresentasekannya. Setelah dilakukan pengukuran awal (post-test) sampel

\section{Dipublikasikan Oleh :}

\section{UPT Publikasi dan Pengelolaan Jurnal}

Universitas Islam Kalimantan Muhammad Arsyad Al-Banjari Banjarmasin 
diberi intervensi (latihan aerobik) berupa jogging selama 12 minggu dengan frekuensi 3 kali dalam seminggu dengan durasi 30 menit, kemudian setelah 12 minggu dilakukan pengukuran kembali IMT, lemak subkutan serta total lemak tubuh sebagai data akhir (post-test).

\section{HASIL PENELITIAN DAN PEMBAHASAN}

Data empiris yang diperoleh di lapangan berupa hasil tes dan pengukuran lemak tubuh berupa pengukuran ketebelan lemak subkutan di 4 titik pengukuran yaitu, bicep, subscapula, abdominal, dan thigh terlebih dahulu diadakan tabulasi data untuk memudahkan pengujian selanjutnya. Analisis data yang digunakan dalam penelitian ini adalah dianalisis dengan teknik statistik infrensial. Analisis data secara deskriptif dimaksudkan untuk mendapatkan gambaran umum data meliputi rata-rata, standar deviasi, varians, data maksimum, data minimum, range, tabel frekuensi dan grafik. Selanjutnya dilakukan pengujian persyaratan analisis yaitu uji normalitas data. Untuk pengujian hipotesis menggunakan uji-t untuk mencari pengaruh latihan aerobik terhadap penurunan lemak subkutan dengan persyaratan data harus dalam keadaan berdistribusi normal.

A. Deskripsi data penelitian

Analisi data deskriptif dimaksudkan untuk mendapatkan gambaran umum data penelitian. Deskripsi data dimaksudkan untuk dapat menafsirkan dan memberi makna tentang data tersebut.

1. IMT, lemak subkutan dan lemak tubuh sebelum Aerobik (Pre-Test).

IMT atau indeks massa tubuh merupakan ekspresi sederhana pengukuran yang berhubungan antara berat badan dan tinggi badan untuk mengetahui status gizi seseorang. Lemak subkutan dalam penelitian ini yaitu, bicep, subscapula, abdominal, dan thigh. Lemak tubuh merupakan persentase dan pengukuran lemak subkutan yang menggambarkan total lemak tubuh. Deskripsi data selanjutnya disajikan pada tabel berikut ini.

\begin{tabular}{lllllll}
\hline & IMT & Bicep & Subscapula & Abdominal & Thigh & $\begin{array}{l}\text { Total } \\
\text { Tubuh }\end{array}$ \\
& & & & & & Lemak \\
\hline $\mathrm{N}$ & 25 & 25 & 25 & 25 & 25 & 25 \\
\hline Mean & 31.25 & 12.57 & 29 & 18.86 & 10.14 & 23.04 \\
\hline Median & 33 & 10 & 22 & 20 & 11 & 22.32 \\
\hline $\begin{array}{l}\text { Std. } \\
\text { Deviation }\end{array}$ & 4.79 & 5.02 & 9.41 & 5.64 & 5.01 & 1.47 \\
\hline Range & 13.10 & 13 & 19 & & & \\
\hline Minimum & 25.60 & 7 & 21 & 15 & 10 & 4.08 \\
\hline Maximum & 38.70 & 20 & 40 & 10 & 5 & 21.88 \\
\hline Sum & 218.80 & 88 & 203 & 25 & 15 & 25.96 \\
\hline
\end{tabular}

Tabel 2. Analisis deskripsi statistik, IMT, lemak subkutan dan lemak tubuh (Pre-Test).

2. IMT, lemak subkutan dan lemak tubuh setelah Aerobik (post-test).

Deskripsi data IMT, lemak subkutan dan lemak tubuh setelah melakukan latihan aerobik disajikan pada tabel berikut:

\begin{tabular}{lllllll}
\hline & \multicolumn{7}{c}{ Deskripsi Statistik } \\
\hline $\mathrm{N}$ & 25 & Bicep & Subscapula & Abdominal & Thigh & Lemak Tubuh \\
\hline Mean & 30.37 & 11.43 & 25.71 & 25 & 25 & 25 \\
\hline Median & 32 & 9 & 20 & 16 & 6.86 & 21.24 \\
\hline Std. Deviation & 4.74 & 4.46 & 8.18 & 5.26 & 6 & 20.53 \\
\hline Range & 12.90 & 11 & 18 & 14 & 4.37 & 1.60 \\
\hline Minimum & 25 & 7 & 18 & 8 & 10 & 4.51 \\
\hline Maximum & 37.90 & 18 & 36 & 22 & 12 & 20.09 \\
\hline Sum & 212.60 & 80 & 180 & 112 & 48 & 148.68 \\
\hline
\end{tabular}

Tabel 3. Analisis deskripsi statistik, IMT, lemak subkutan dan lemak tubuh (Post-Test).

B. Pengujian Prasyarat Analisis

\section{Dipublikasikan Oleh :}

\section{UPT Publikasi dan Pengelolaan Jurnal}

Universitas Islam Kalimantan Muhammad Arsyad Al-Banjari Banjarmasin 
Data pada penelitian ini dianalisis dengan menggunakan uji-t amatan ulangan (pairs-test) yaitu membedakan antara sebelum dan sesudah melakukan latihan aerobik. Pengujian prasyarat yang harus dipenuhi adalah data berdistribusi normal. Pengujian normalitas data pada penelitian ini menggunkan uji Kolmogrov Smirnov Z. Hasil pengujian normalitas sebaran secara ringkas disajikan pada tabel berikut ini:

Tabel 4. Hasil uji normalitas

\begin{tabular}{|c|c|c|c|}
\hline \multirow{2}{*}{$\begin{array}{c}\text { Waktu Pengambilan } \\
\text { Data }\end{array}$} & \multicolumn{3}{|c|}{ Kolmogrov Smirnov } \\
\hline & Variabel & thes & Kesimpulan \\
\hline \multirow{6}{*}{ Pre-Test } & IMT & 0.90 & Normal \\
\hline & Bicep & 0.70 & Normal \\
\hline & Subscapula & 0.38 & Normal \\
\hline & Abdominal & 0.94 & Normal \\
\hline & Thigh & 0.66 & Normal \\
\hline & Lemak Tubuh & 0.21 & Normal \\
\hline \multirow{6}{*}{ Post-Test } & IMT & 0.92 & Normal \\
\hline & Bicep & 0.65 & Normal \\
\hline & Subscapula & 0.43 & Normal \\
\hline & Abdominal & 0.93 & Normal \\
\hline & Thigh & 0.74 & Normal \\
\hline & Lemak Tubuh & 0.64 & Normal \\
\hline
\end{tabular}

Tabel tersebut di atas menunjukkan bahwa data berdistribusi normal yang ditunjukkan dengan Kolmogrov Smirnov Z Test semuanya tidak signifikansi pada taraf signifikansi 5\% (p>0,05). Dengan demikian prasyarat uji normalitas data telah terpenuhi.

C. Analisis Data

Hipotesis pada penelitian ini adalah: "terdapat pengaruh aktivitas aerobik terhadap perubahan indeks massa tubuh dan penurunan lemak subkutan". Hipotesis tersebut diuji dengan teknik analisis statistik uji-t ( $\boldsymbol{t}$ test) amatan ulangan (Pairs t-tesi), hasil analisis statistik secara ringkas disajikan pada tabel berikut ini: Tabel 5. Hasil Uji Hipotesis

\begin{tabular}{|c|c|c|c|c|c|c|}
\hline Variabel & Waktu & Mean & SD & T-Hitung & P-Value & Keterangan \\
\hline \multirow{2}{*}{ IMT } & Pre-test & 31.25 & 4.79 & \multirow{2}{*}{13.98} & \multirow{2}{*}{0.00} & \multirow{2}{*}{ Signifikan } \\
\hline & Post-test & 30.37 & 4.74 & & & \\
\hline \multirow{2}{*}{ Bicep } & Pre-test & 12.57 & 5.02 & \multirow{2}{*}{3.36} & \multirow{2}{*}{0.00} & \multirow{2}{*}{ Signifikan } \\
\hline & Post-test & 11.43 & 4.46 & & & \\
\hline \multirow{2}{*}{ Subscapula } & Pre-test & 29 & 9.41 & \multirow{2}{*}{6.29} & \multirow{2}{*}{0.00} & \multirow{2}{*}{ Signifikan } \\
\hline & Post-test & 25.71 & 8.18 & & & \\
\hline \multirow{2}{*}{ Abdominal } & Pre-test & 18.86 & 5.64 & \multirow{2}{*}{10.95} & \multirow{2}{*}{0.00} & \multirow{2}{*}{ Signifikan } \\
\hline & Post-test & 16 & 5.26 & & & \\
\hline Thigh & Pre-test & 10.14 & 5.01 & 7.81 & 0.00 & Signifikan \\
\hline
\end{tabular}

\section{Dipublikasikan Oleh :}

\section{UPT Publikasi dan Pengelolaan Jurnal}

Universitas Islam Kalimantan Muhammad Arsyad Al-Banjari Banjarmasin 


\begin{tabular}{lcccccc}
\hline & Post-test & 6.86 & 4.37 & & & \\
\hline \multirow{2}{*}{ Lemak Tubuh } & Pre-test & 23.04 & 1.47 & \multirow{2}{*}{13.06} & \multirow{2}{*}{0.00} & \multirow{2}{*}{ Signifikan } \\
\cline { 2 - 4 } & Post-test & 21.24 & 1.60 & & \\
\hline
\end{tabular}

Dari tabel di atas menunjukkan bahwa IMT, lemak subkutan (bicep, subscapula, abdominal, thigh) dan lemak tubuh didapatkan masing-masing nilai $\mathrm{P}=0,00$, pada taraf signifikansi $5 \%$ maka $\mathrm{p}<0,05$. Dari hasil tersebut dapat disimpulkan bahwa ada perbedaan yang signifikan IMT, lemak subkutan (bicep, subscapula, abdominal, thigh) dan lemak tubuh antara sebelum dan sesudah melakukan treatment (latihan aerobik).

\section{Pembahasan}

Hasil - hasil analisis efek latihan aerobik antara tes awal (pre-test) dan tes akhir (post-test) terhadap variabel terikat. Untuk pengujian hipotesis perlu dikaji lebih lanjut dengan memberikan interpretasi keterkaitan antara hasil analisis yang dicapai dengan teori-teori yang mendasari penelitian ini. Penjelasan ini diperlukan agar dapat diketahui kesesuaian teori-teori yang dikemukakan dengan hasil penelitian yang diperoleh. Ada pengaruh yang signifikan latihan aerobik terhadap penurunan indeks massa tubuh dan penurunan lemak subkutan.

Satu-satunya cara membuang simpanan lemak subkutan adalah dengan membakarnya dan kita telah mengetahui bahwa latihan meningkatkan pengeluaran energi dan tingkat pengeluaran tersebut berkaitan dengan intensitas dan durasi latihan. Dalam tubuh lemak disimpan dalam bentuk trigliserida pada jaringan adipose atau jaringan lemak yang terdapat dibawah kulit yang dikenal sebagai lemak subkutan. Salah satu cara untuk mengurangi lemak dengan berolahraga untuk meningkatkan pengeluaran kalori dengan memaksimalkan lemak menjadi energi sehingga tidak terjadi penumpukan lemak berlebih dalam tubuh. Dalam memecah lemak menjadi energi dibutuhkan oksigen yang cukup. Oleh karena itu dalam pemilihan aktifitas fisik atau olahraga dalam hal pembakaran lemak dengan melihat penyediaan oksigen atau sistem energi olahraga tersebut.

Latihan aerobik adalah latihan dengan penggunaaan sistem energi aerob dengan kebutuhan akan oksigen. Oleh karena itu latihan aerobik sangat cocok untuk mengurangi atau menurunkan lemak subkutan dan lemak tubuh. Pada saat melakukan latihan aerobik tubuh akan melakukan metabolisme energi dari lemak melalui pemecahan simpanan lemak yang terdapat didalam tubuh. Didalam tubuh lemak disimpan dalam jaringan adiposa serta dalam sel otot. Melalui proses yang dinamakan loposis, lemak akan dikonversi menjadi asam lemak dan gliserol. Gliserol yang terbentuk akan masuk ke dalam siklus metabolisme untuk diubah menjadi glukoa atau juga asam piruvat. Sedangkan asam lemak yang terbentuk akan dipecah menjadi unit-unit kecil melalui proses yang dinamakan beta oksidasi untuk kemudian menghasilkan energi ATP di dalam mitokondria sel.

Latihan aerobik biasa juga dikaitkan dengan kebugaran aerobik atau daya tahan umum (kardiorespiratori). Penurunan lemak subkutan dan lemak tubuh disebabkan oleh meningkatnya aktifitas fisik yang semula melakukan olahraga hanya seminggu sekali pada pembelajaran olahraga di sekolah menjadi 3 kali seminggu dengan intensitas rendah dalam durasi atau waktu yang cukup lama selama 30 menit yang mana sumber energi yang dibutuhkan berasal dari pembakaran cadangan lemak tubuh. Hal ini sesuai dengan pendapat (Sharkey, 2011)yang menyatakan bahwa latihan aerobik memiliki efek terhadap otot diantaranya meningkatkan kemampuan otot untuk menggunakan lemak sebagai sumber energi. Dengan meningkatnya aktifitas fisik menyebabkan terbakarnya cadangan lemak untuk memenuhi kebutuhan energi tubuh pada saat menjalani latihan. Otot yang terlatih terbiasa menggunakan sumber energi, apabila oksigen mencukupi maka metabolisme energi akan menggunakan cadangan energi yang banyak atau bahkan yang berlebih yaitu karbohidrat (glukosa) serta lemak dan menghemat persediaan karbohidrat yang terbatas (glikogen) dalam otot dan hati. Yang paling penting dari semua ini, latihan meningkatkan metabolisme lemak. (Sharkey, 2011)menyatakan bahwa latihan meningkatkan kemampuan oksidasi otot yang menghasilkan produksi asam laktat yang lebih sedikitdan metabolisme lemak yang lebih besar.

Penurunan lemak subkutan merupakan dampak dari latihan aerobik yang pada dasarnya memanfaatkan oksigen pada saat latihan dalam metabolisme lemak untuk penyediaan energi khususnya lemak yang ada di bawah kulit (subkutan). Selain itu pada dasarnya latihan aerobik juga mendorong pada peningkatan kebugaran aerobik atau daya tahan umum. Jogging adalah olahraga yang banyak melibatkan otot, selain kumpulan otot bawah (paha dan betis), perut yang juga terlibat dalam menopang ketegakan tubuh dan juga subscapula dan bisep yang berperan pada ayunan tangan saat jogging dalam keseimbangan gerak tubuh. Endurance adalah olahraga yang mengikutsertakan otot sebanyak mungkin dan melatih ketahanan jantung dan paru. Karena kumpulan otot banyak berada di bawah (kaki, paha) dan di atas (punggung, dada) maka gerak tubuh yang cocok adalah senam

\section{Dipublikasikan Oleh :}

\section{UPT Publikasi dan Pengelolaan Jurnal}

\section{Universitas Islam Kalimantan Muhammad Arsyad Al-Banjari Banjarmasin}


aerobik atau jogging. Selain itu faktor-faktor seperti peningkatan insulin dan suhu tubuh juga mempercepat laju metabolisme yang kemudian mengarah ke metabolisme lemak.

Hal inilah yang mempengaruhi penurunan indeks masssa tubuh dimana penggunaan lemak sebagai energi tentunya akan mempengaruhi ketebalan lemak subkutan dan persentase total lemak dalam tubuh yang juga berdampak pada penurunan berat badan yang berinterpretasikan terhadap penurunan indeks massa tubuh. Walaupu pada dasarnya latihan aerobik juga sangat efektif dalam mengontrol berat badan. Aktifitas yang sedang disarankan untuk mengontrol berat badan, bukan latihan yang intensitasnya tinggi (Sharkey, 2011). Individu yang bugar secra fisik dapat memperoleh sejumlah besar persentase kebutuhan energi dari lemak dibandingkan dengan individu yang tidak bugar. Pada beban kerja tertentu, subjek yang bugar dapat memperoleh sebesar $90 \%$ energinya dari lemak. Asam lemak bebas digunakan dalam semua bentuk aktivitas otot kecuali untuk gerakan yang mendadak. Latihan bahkan meningkatkan kemampuan otot jantung untuk mengoksidasi lemak (Sharkey, 2011).

\section{PENUTUP}

Kesimpulan

Terdapat pengaruh yang signifikan latihan aerobik terhadap penurunan indeks massa tubuh dan ketebalan lemak subkutan yang juga akan berdampak pada penurunan total lemak tubuh.

Saran

Untuk menurunkan indeks massa tubuh dan lemak subkutan, maka olahraga yang tepat adalah olahraga aerobik. Untuk memaksimalkan program penurunan indeks massa tubuh, lemak subkutan serta total lemak tubuh, maka latihan aerobik harus diikuti dengan pola makan yang sehat.

\section{REFERENSI}

Akhmad, I. (2015). Efek Latihan Berbeban Terhadap Fungsi Kerja Otot. Jurnal Pedagogik Keolahragaan 1(2).

Azrimaidaliza., Resmiati., Famelia, W., Purnakarya, I., Firdaus., Khairany, Y. (2020). Dasar Gizi Ilmu Kesehatan Masyarakat. Padang: Universitas Andalas.

Dinata, M., Jubaedi, A., Surisman. (2020). Pelatihan senam middle aerobik di kabupaten pesawaran provinsi lampung. Jurnal Sumbangsih, 1,106-113.

Kandinasti, S. (2018). Obesitas: Pentingkah Memperhatikan Konsumsi Makanan di Akhir Pekan? Obesity: Is It Important to Concern about Food Intake in The Weekend? Amerta Nutr, 1-12. https://doi.org/10.2473/amnt.v2i4.2018.307-316.

Kurdanti, W., Suryani, I., Syamsiatun, N.H., Siwi, L.P., Adityanti, M.M., Mustikaningsih, D., Sholihah, K.I. (2015). Faktor-faktor yang mempengaruhi kejadian obesitas pada remaja. Jurnal Gizi Klinik Indonesia Vol 11, Issue 4, 179-190.

Lesmana, H.S. (2018). Bahan Ajar Fisiologi Olahraga. Padang: UNP.

Listiarini, D., Junaidi, S., Subiyono, H.S. (2018). Kombinasi latihan aerobik dan asupan kafein untuk menurunkan body mass index dan percent body fat pada wanita overweight. Jurnal Media Ilmu Keolahragaan Indonesia,8,1. http://journal.unnes.ac.id/nju/index.php/miki.

Ngurah Adi Santika, I.G.P. (2016). Pengukuran tingkat kadar lemak tubuh melalui jogging selama 30 menit mahasiswa putra semester IV FPOK IKIP PGRI Bali. Jurnal Pendidikan Kesehatan Rekreasi, 1, 89- 98.

Nurhayati, T. (2018). Hubungan Aktivitas Fisik Dengan Lingkar Pinggang Pada Masyarakat Kecamatan Cijulang Kabupaten Pangandaran Jawa Barat. Jurnal Pendidikan Jasmani Dan Olahraga, 3(2). https://doi.org/10.17509/jpjo.v3i2.12640.

Oktriani, S. (2019). Physical Activity in Elderly: An Analysis of Type of Sport Taken by Elderly in Bandung. Jurnal Pendidikan Jasmani Dan Olahraga, 4(1). https://doi.org/10.17509/jpjo.v4i1.15059.

P2PTM Kemenkes. (2018). Klasifikasi Obesitas setelah pengukuran IMT - Direktorat P2PTM. Http://P2ptm.Kemkes.Go.Id/.

Sharkey, B. J. (2011). Kebugaran dan Kesehatan (1st-2nd ed.). Rajawali Press.

Sientia, F., \& Puruhita, N. (2012). Pengaruh Latihan Senam Aerobik Terhadap Perubahan Berat Badan Pada Peserta Klub Kebugaran. Jurnal Media Medika.

Susiwati., sunita R.S., Farizal, J. (2018). Analysis of Cholesterol Low Density Lipoprotein (LDL) On Consumption Of "X" Herbal Beverage Products In Bengkulu City 2017. JNPH, 6(2), 95-99.

Yani, M. (2015). Mengendalikan Kadar Kolesterol Pada Hiperkolesterolemia. Jurnal Prestasi Olahraga,11(2).

\section{Dipublikasikan Oleh :}

\section{UPT Publikasi dan Pengelolaan Jurnal}

Universitas Islam Kalimantan Muhammad Arsyad Al-Banjari Banjarmasin 
Dipublikasikan Oleh :

UPT Publikasi dan Pengelolaan Jurnal

Universitas Islam Kalimantan Muhammad Arsyad Al-Banjari Banjarmasin 